\title{
症例報告
}

\author{
食事指導と食物経口負荷試験により \\ 卵・小麦の完全除去が解除できた食物アレルギーの幼児例 \\ 林 利佳 ${ }^{1,2)}$ 赤嶺 ゆみ ${ }^{1,3)}$ 小川えりか ${ }^{2)}$ \\ 橋本 光司 ${ }^{1,4)}$ 稲毛 康司 ${ }^{1)}$ \\ 1) 日本大学医学部小児科学系小览科学分野 \\ 2) 日本大学病院総合診療センター小览科 \\ ${ }^{3)}$ 社会医療法人友愛会豊見城中央病院小览科 \\ 4) ときわ台はしもと小児科アレルギー科
}

\section{A Food Allergic Child who was Treated Successfully for Egg and Wheat Allergy by Oral Food Challenge and Dietary Intervention}

\author{
Rika HAYASHI ${ }^{1,2)}$, Yumi AKAmine ${ }^{1,3)}$, Erika OGAWA ${ }^{2)}$, \\ Koji Hashimoto ${ }^{1,4)}$ and Yasuji InAmo ${ }^{1)}$ \\ ${ }^{1)}$ Department of Pediatrics and Child Health, Nihon University School of Medicine \\ ${ }^{2)}$ Department of Pediatrics, Nihon University Hospital \\ ${ }^{3)}$ Department of Pediatrics, Tomishiro Central Hospital \\ ${ }^{4)}$ Tokiwadai Hashimoto Children's Clinic
}

Background: There have been few practical reports of dietary intervention near the threshold of allergic reactions for food allergy. Herein, we report a case of a food allergic child who was successfully treated for egg and wheat allergy by oral food challenge (OFC) and dietary intervention, not oral immunotherapy.

Case presentation: A 4-year-old boy who developed anaphylaxis at seven months of age. He showed high specific IgE values and was skin prick test-positive for egg, milk, and wheat. He was recommended to completely avoid these allergens by a previous doctor. He experienced six incidences of food-induced anaphylaxis to these allergens before visiting our hospital. We repeatedly instructed the patient in dietary management at the outpatient department. Consequently, he managed to avoid the restriction of wheat and egg and achieved a satisfactory diet menu.

Conclusion: We concluded that the elimination of allergens is possible by gradually increasing the target dose of causative foods under evaluation by OFC.

Key words: dietary intervention, elimination diet, food allergy, oral food challenge test, oral immunotherapy 食事指導，除去解除，食物アレルギー，食物経口負荷試験，経口免疫療法

(J. Nihon Univ. Med. Ass., 2018; 77 (3): 175-180)

要旨 食物アレルギーに対し, 食品除去解除に向けた 食事指導の具体的な報告は少ない，食物経口負荷試験の 評価と食事指導で除去解除が出来た卵，牛乳，小麦アレ ルギーの幼児例を報告する。生後 7 か月にアナフィラキ シ一を認め, 皮膚検查と特異的 IgE 抗体検査が陽性で完 全除去を指示された。初診までに 6 回ものアナフィラキ シ一歴があったが，小麦と卵は解除が出来た。厳格除去 食の場合も, 経口免疫療法によらず食事指導で解除は可 能である

\section{はじめに}

栄養食事指導や経口免疫療法 (oral immunotherapy: OIT) の適切な施行をするためのプロトコルを，各施設 が経験に基づいて作成しておくことが重要とされる ${ }^{11}$. 食物アレルギーは乳児〜幼児期に発症することが多く， 成長とともに治っていくことは明らかである2). しかし， 経年的な食物抗原別の耐性獲得時期や獲得率変化を抗原 特異的 IgE 抗体価との関連性で検討した報告は少なく耐 性獲得の予測は困難である ${ }^{3,4)}$. 耐性化遷延には，ア下 ピー性皮膚炎の遷延化や総除去品目数の多さなどが一因 
と明らかにされ適切な患者指導に重要な情報である5). 学童期以降では自然緩解が期待しにくく, 食べて治す療 法は理論的根拠がまだ不十分ではあるが，早期に食事指 導を開始することは長期にわたる除去食から解き放つ有 効な手段である ${ }^{6)}$.

我々の食物アレルギー児に対する食事指導は，以前か ら安全に食べられる量を少しずつ摂取し増量していく方 法であったが，経験的で系統的ではなかった。今回は外 来診療にて卵，牛乳，小麦の食物アレルギー児に対し 「食べること」を前提に，系統的で定量的に低アレルゲ ン化した低量域免疫寛容をめざした食品の摂取量を増量 できた症例を経験したので，治療経過について若干の考 察を加えて報告する。

\section{症例}

症例：4 歳 1 か月男児.

主訴：食物アレルギーの再評価と除去食の解除につい $\tau$.

家族歴：父親が気管支喘息，アトピー性皮膚炎，卵ア レルギー。

食物アレルギー以外のアレルギー既往歴：生後まもな くからアトピー性皮膚炎に罹患し, 1 歳時までステロイ ド外用薬を使用していた。最近は保湿剤と間欠的にステ ロイド外用薬を使用する程度であり，初診時にはコント ロールは良好であった。2 歳 6 か月時に気管支喘息と診 断され吸入ステロイド薬と抗ロイコトリエン受容体拮抗 薬内服による治療を継続していた。喘息発作での入院歴 はなく，最終発作は 3 歳 11 か月であった。

食物アレルギー（アナフィラキシー）歴：7 か月に乳 児用スプーンの先に少量のヨーグルトをつけて舐めさせ 全身蓴麻疹と下痢が出現した。9 か月に素麺 1 本を摂取 して全身の紅斑と咳嗽，下痢が出現した。近医を受診し 卵白，牛乳，小麦の皮膚プリックテストと抗原特異的 $\operatorname{IgE}$ 抗体検査を受けた。いずれも結果が陽性であり 3 食 品の完全除去が開始となった。

1 歳 3 か月にフライドポテト 3 本の小麦の衣, 2 歳 6 か月にはんぺん大匙 1 杯, 3 歳 3 か月に少量の炒り卵,

3 歳 5 か月に市販の牛タン弁当のカゼインの摂取が原因 で全身紅斑と蕁麻疹, 咳嗽と喘鳴, 複数回の下㾥などの アレルギー症状が出現した。過去に少量の食物が原因で 合計 6 回のアナフィラキシー歴があった。

現病歴：4歳時健診で低身長を指摘されたため当院の 小児内分泌外来を紹介受診し, 精査の結果は体質性低身 長と診断された。食物アレルギーに対してアレルギー食 品の完全除去を指示されていたため, 解除の目的で小览 アレルギー外来を再受診となった.

アレルギー外来初診時の現症 : 身長 $92.5 \mathrm{~cm}(-2.1 \mathrm{SD})$, 体重 $13.9 \mathrm{~kg}$ (-0.7SD). 呼吸音, 心音, 腹部所見に特記 すべき異常はなし。皮膚は軽度乾燥を伴っていた。検
Table 1 Laboratory data on admission

\begin{tabular}{|lc|}
\hline WBC & $8,200 / \mu \mathrm{l}$ \\
Eosino & $3.0 \%$ \\
$\mathrm{Hb}$ & $12.9 \mathrm{~g} / \mathrm{dl}$ \\
非特異的 $\mathrm{IgE}$ & $282 \mathrm{IU} / \mathrm{ml}$ \\
特異的 $\mathrm{IgE}$ 抗体価 & \\
卵白 & $18.5 \mathrm{U}_{\mathrm{A}} / \mathrm{ml}$ \\
オボムコイド & $20.4 \mathrm{U}_{\mathrm{A}} / \mathrm{ml}$ \\
牛乳 & $47.3 \mathrm{U}_{\mathrm{A}} / \mathrm{ml}$ \\
カゼイン & $18.5 \mathrm{U}_{\mathrm{A}} / \mathrm{ml}$ \\
小麦 & $2.08 \mathrm{U}_{\mathrm{A}} / \mathrm{ml}$ \\
の5-グリアジン & $1.37 \mathrm{U}_{\mathrm{A}} / \mathrm{ml}$ \\
TARC & $498 \mathrm{pg} / \mathrm{ml}$ \\
\hline
\end{tabular}

査所見は血算・像, 生化学一般検査に特記すべき異常 はなかった。総 $\mathrm{IgE}$ 值は $282 \mathrm{IU} / \mathrm{ml} （ 3 \sim 5$ 歳未満の基 準值 $40 \mathrm{IU} / \mathrm{ml}$ 以下)，抗原特異的 $\operatorname{IgE}$ 抗体価は卵白 18.5 $\mathrm{U}_{\mathrm{A}} / \mathrm{ml}$, オボムコイド $20.4 \mathrm{U}_{\mathrm{A}} / \mathrm{ml}$, 牛乳 $47.3 \mathrm{U}_{\mathrm{A}} / \mathrm{ml}$, カ ゼイン $18.5 \mathrm{U}_{\mathrm{A}} / \mathrm{ml}$ ，小麦 $2.08 \mathrm{U}_{\mathrm{A}} / \mathrm{ml}, \omega 5$ グリアジン 1.37 $\mathrm{U}_{\mathrm{A}} / \mathrm{ml}$ といずれも陽性を示していた。 TARC (thymus and activation-regulated chemokine) は基準範囲内であった (Table 1).

経過：本症例の場合は，血液検査所見と今までのアナ フィラキシー症状を考慮して小麦, 卵黄, 牛乳, 卵白 の順に食物経口負荷試験 (oral food challenge test: OFC) を 行った。それぞれの OFC の合間に食事指導をつづけた。 またアレルギー外来受診までに未摂取だった食品は，抗 原特異的 $\operatorname{IgE}$ 抗体価が低いそばは小麦の摂取が進んだの ちに，魚卵のいくらやタラコも外来受診時に単回摂取を 行い, 経過中に解除することが出来た

本症例の具体的な治療の内容：まず小麦は, ゆでうど ん合計 $8.5 \mathrm{~g}$ を 4 分割し 30 分ごとの OFCで検査結果は 㓌性であった。自宅でゆでうどん $4 \mathrm{~g}$ からの摂取開始を 指導した。自宅で $15 \mathrm{~g}$ を摂取できた頃から資料 ${ }^{7)}$ も利 用した。経過中に数回, 数個の躕麻疹を認めることがあっ たがアナフィラキシーは発症しなかった。 小麦の食事指 導を開始し 12 か月後にはゆでうどん $200 \mathrm{~g}$ と加工品も それ相当を摂る事ができるようになった。

次に卵は，20 分の固ゆで卵黄 $10.5 \mathrm{~g}$ を 4 分割し OFC を施行，結果は陰性。自宅で 20 分の固ゆで卵黄 $2 \mathrm{~g}$ か らの摂取を指導した。卵黄一個分の摂取ができたことを 確認し，卵白を耳かき一匙摂取した。固ゆで卵白 $5 \mathrm{~g}$ ま でを摂取出来た事を確認し，加工品の摂取の指導も開始 した。徐々に加工品や錦糸卵で卵白の摂取量を増量し た。卵黄摂取開始から 16 か月後には卵白 $17 \mathrm{~g}$ の摂取が 可能になったことを固ゆで卵白の OFCで確認した。20 か月後には加工品は除去の必要がなく，加熱卵白は $2 / 3$ 個まで，茶碗蒸しは二口，マヨネーズは少量の摂取が可 能になった。

牛乳は $0.05 \mathrm{ml}, 0.1 \mathrm{ml}, 1.0 \mathrm{ml}$ の順で増量した $\mathrm{OFC}$ では, $1.0 \mathrm{ml}$ 摂取 5 分後に全身蕁麻疹と喘鳴が出現し結 
果は陽性であった。牛乳 $0.05 \mathrm{ml}$ 以下の摂取の指導を開 始した。牛乳の食事指導を開始し 24 か月後でも飲用牛 乳は $0.13 \mathrm{ml}$ までと増量がかなり困難であり, 超熟食パ ン 6 枚切りでは一口が摂取できる程度の状況であり注意 深く食事指導を続けている。摂取できた食品の量と加工 食品, 指導中に生じたアレルギー症状を表に示した (Table 2).

食事指導中にアトピー性皮膚炎と喘息の悪化は認めな かった。その他に重症な有害事象の出現もなかった。食 事除去の解除が進んでも-2.1SD と低身長に変化は認め なかった。

3 食品の摂取できた食品の量と特異的抗体価の推移を 示した (Fig. 1)。麦は摂取量の増量に伴い，小麦と $\omega 5$ グリアジンの抗体価は逆に低下した。卵は卵黄摂取だけ の時期でも卵白とオボムコイドの抗体価が低下していた。 牛乳とカゼインの抗体価は緩やかに低下していた。総 $\operatorname{IgE}$ 值と抗原特異的 $\operatorname{IgE}$ 抗体価との経過では卵，牛乳， 小麦の摂取を開始以降は明らかに 3 食品の抗原特異的 IgE 抗体価の低下を確認できた (Table 3).

\section{考案}

食物アレルギーの診断には，特異的 $\operatorname{IgE}$ 抗体価や皮膚 プリックテストなどの客観的な指標が用いられるが，そ の結果だけでは食物アレルギーの診断は出来ず OFCの 結果をもって確定するのが原則である ${ }^{8,9)}$. 特異的 $\operatorname{IgE}$ 抗体が陽性でも，食物による症状誘発の既往が無ければ 診断は確定したわけではなく，その後の OFCで陰性が 確認されることも少なくない ${ }^{10)}$

食物アレルギーの治療は，必要最小限の原因食物のみ を除去することが基本であり，念のためになど根拠のな い不必要な食物除去は行わない" ${ }^{11)}$ とある。しかし OFC の結果に基づいた除去解除にむけた治療の具体的で十分 な記載は少ない

OIT は，「早期に耐性獲得が期待できない重症の患児 に対し，一定の計画性を持ってアレルゲンを摂取させ， 増量しながら耐性獲得を誘導する治療」1)であり対象と なる患児が限られる研究段階の治療である。

免疫学の領域では, 経口摂取した抗原に対して特異的 に免疫抑制が起こることはよく知られており経口免疫 寛容とよばれる ${ }^{12)}$ 。食事制限を継続している場合には， OFC による評価と外来での食事指導による経口免疫寛 容の適応を見極める必要がある。

当科アレルギー外来での食物アレルギーの診療方針 は，軽症から中等症の学童期前までの児を対象に外来で 食事指導を行っている。多くは自宅で極少量の食物から 摂取していく指導である。10 年以上前の指導では，「加 熱や発酵した食品, 加工食品を極少量から」と定量性が 不十分な診療を行っていた。経験的で曖昧な指導にな り，保護者の理解や食生活の違いなどが原因で除去解除
が困難なケースも少なくなかった。

現在は，患児の背景により開始量は様々ではあるが, 多くは卵の場合には20 分の固ゆで鶏卵の卵白あるいは 卵黄を耳かき 1 匙又は米 1 粒位から，牛乳の場合は牛乳 タンパク質含有レベル ${ }^{13)}$ の低い加工品またはヨーグル 卜を 1 滴から，小麦の場合は乾燥素麺 1 本またはゆでう どん $1 \mathrm{~cm}$ から開始している。十分な安全域を見込み $2 \mathrm{~g}$ 以下の極微量から開始することが多い. 食物日誌を用い て週に $2 \sim 3$ 回以上, $1 \sim 2$ 週間の間に 3 回以上の攝取 を繰り返す。アレルギー症状が出現しないことを確認し て 1.2〜1.5 倍ずつの増量を明確に指示している。保護者 には，誘発症状で複数の蕁麻疹や軽い咳などに対しては あらかじめ処方した抗ヒスタミン薬の内服, それ以上の 症状が出現した場合には病院受診の指導もしている.

体調不良時などは中止し, 摂取できない期間がある場 合は摂取量を減らして再開することを説明している。約 一か月毎の外来診療で増量できたことを確認し，一定量 以上の摂取が可能になった場合には加工食品や料理に使 用して増量している，最近では“おいしく治す食物アレ ルギー攻略法 ${ }^{7)}$ の資料も利用し定量的に食べられる範 囲と量を徐々に増加させている。アドヒアランスが不良 な症例や重症度の高い患児は必要に応じて OFC を参考 にしている。

患者本人や家族の負担も考慮し，患者全員に適応でき る OIT とは異なる ${ }^{14)}$ 少量摂取から始める食事指導が除 去食の解除には重要と考えている.

今後はアレルゲン食品の摂取内容・量をより具体的に 示せるよう取り組む必要がある。食品の特性と加熱・調 理などによる抗原性の低減化について理解し, 低アレル ゲン化した食品の積極的食事指導で摂取を促すことは, 早期のアウトグローにつながる可能性があり食物アレル ギー巟および家族の QOL を向上させる ${ }^{15)}$.

今回は OFC や食事指導の具体的な内容と経過を示し た。食物アレルギーの診療のゴールは, 耐性を獲得し解 除まで導くことである。閾值を超えた摂取を重症例に指 導することが OIT に相当するという観点から，少量の摂 取可能量を確認した後に「安全域を見込んた摂取量の範 囲」を評価し，増量できる可能性を繰り返し検討しなが $ら^{14)}$ 極少量ずつ緩徐に摂取していく方法は，食物アレ ルギーの診療に十分な経験をもつ医師が，慎重できめ細 かい指導の上，一般外来でも出来る方法となり得ると考 えている.

安全性は，小林らの最低摂取開始量 $2 \mathrm{~g}$ と設定した食 事指導方法では，摂取指導中に軽微なアレルギー症状を 認めたが，OFC 陽性者と陰性者とを比較して有意な差 は認めなかったと報告されている ${ }^{16)}$ ，当院の食事指導で は，軽微なアレルギー症状はあるが，その他アレルギー 疾患の悪化や非即時型の副反応の経験もない。誤食や保 護者の誤解による摂取量過多にも注意している。食事 
Table 2 Dietary intervention of wheat, egg and cow's milk

\begin{tabular}{|c|c|c|c|}
\hline $\begin{array}{c}\text { 小麦 } \\
\text { 摂取開始後 }\end{array}$ & ゆでうどん量 & $\begin{array}{c}\text { 加工品を } \\
\text { うどんの量に換算 }\end{array}$ & アレルギー症状と摂取できた加工品など \\
\hline 1 か月 & $7 \mathrm{~g}$ & & ゆでうどん $6 \mathrm{~g}$ : 頸に蓐麻疹数個 \\
\hline 2 か月 & $9 \mathrm{~g}$ & & \\
\hline 3 か月 & $12 \mathrm{~g}$ & & ゆでうどん $12 \mathrm{~g}$ ：顔面萇麻疹（卵黄負荷試験） \\
\hline 4 か月 & $18 \mathrm{~g}$ & & \\
\hline 5 か月 & $20 \mathrm{~g}$ & $5 \mathrm{~g}$ & $\begin{array}{l}4 \text { 割そば } 20 \mathrm{~g} \text { 単回摂取 } \\
\text { から揚げ } 3 \text { 個 }\end{array}$ \\
\hline 6 か月 & $24 \mathrm{~g}$ & & 4 割そば $25 \mathrm{~g}$ \\
\hline 7 か月 & $24 \mathrm{~g}$ & & フライドチキン 1 個 \\
\hline 8 か月 & $35 \mathrm{~g}$ & $30 \mathrm{~g}$ & 餃子 1 個, コロッケ 1 個 \\
\hline 9 か月 & $45 \mathrm{~g}$ & $30 \mathrm{~g}$ & シュウマイ 1 個, かき揚げ $1 / 2$ 個 \\
\hline 10 か月 & $50 \mathrm{~g}$ & $50 \mathrm{~g}$ & $\begin{array}{l}\text { フランスパン } 14 \mathrm{~g} \text { : 頸に薵麻疹 } \\
\text { 食パン } 1 / 4 \text { 枚, シュウマイ } 5 \text { 個 }\end{array}$ \\
\hline 11 か月 & $86 \sim 100 \mathrm{~g}$ & $90 \mathrm{~g}$ & 餃子 3 個 \\
\hline 12 か月 & $120 \sim 200 \mathrm{~g}$ & $200 \mathrm{~g}$ & $\begin{array}{l}\text { フランスパン } 50 \mathrm{~g}, \text { 中華麺 } 1 / 2 \text { 玉 } \\
\text { あんまん, 肉まん } 1 / 2 \text { 個 }\end{array}$ \\
\hline 13 か月 & $200 \mathrm{~g}$ & $200 \mathrm{~g}$ & \\
\hline \multicolumn{4}{|c|}{ 小麦解除 } \\
\hline
\end{tabular}

\begin{tabular}{|c|c|c|c|}
\hline $\begin{array}{c}\text { 卵 } \\
\text { 摂取開始後 }\end{array}$ & $\begin{array}{l}\text { 固ゆで } \\
\text { 卵黄 }\end{array}$ & $\begin{array}{c}\text { 加工品を } \\
\text { 卵白の量に換算 }\end{array}$ & アレルギー症状と摂取できた加工品など \\
\hline 1 か月 & $6 \mathrm{~g}$ & & \\
\hline 2 か月 & $9 \mathrm{~g}$ & & \\
\hline 3 か月 & $12 \mathrm{~g}$ & & \\
\hline 4 か月 & $14 \mathrm{~g}$ & & 20 分かたゆで卯白耳かき 1 匙：軽度の嘔気, 腹痛 \\
\hline 5 か月 & $15 \mathrm{~g}$ & & 卵黄炒り卵 $10 \mathrm{~g}$ ：下痢, 腹痛 \\
\hline 6 か月 & \multirow{8}{*}{ 解除 } & つなぎ & 錦系卵 $2 \mathrm{~g}$, つなぎ食品 \\
\hline 7 か月 & & $3 \mathrm{~g}$ & 錦糸卵 $3 \mathrm{~g}$ \\
\hline 8 か月 & & $5 \mathrm{~g}$ & $\begin{array}{l}\text { 固ゆで全卵 } 1 / 8 \text { 個 } \\
\text { ホットケーキ全卵 } 5 \mathrm{~g}\end{array}$ \\
\hline 9 か月 & & $7.5 \mathrm{~g}$ & 炒り卵 $6 \mathrm{~g}$, ケーキ全卵 $7 \mathrm{~g}$ \\
\hline 10 か月 & & $8 \mathrm{~g}$ & 固ゆで卵白 $8 \mathrm{~g}$ \\
\hline 11 か月 & & $10 \mathrm{~g}$ & $\begin{array}{l}\text { 全卵 } 1 / 5 \text { 個, 炒り卵 } 10 \mathrm{~g} \\
\text { 錦糸卵 } 12 \mathrm{~g} \text {, カステラ } 1 / 2 \text { 切れ } \\
\text { ホットケーキ全卵 } 10 \mathrm{~g}\end{array}$ \\
\hline 14 か月 & & $12 \mathrm{~g}$ & ホットケーキ全卵 $12 \mathrm{~g}$ \\
\hline 16 か月 & & $17 \mathrm{~g}$ & 卵白負荷試験 \\
\hline
\end{tabular}

\begin{tabular}{|c|c|c|}
\hline $\begin{array}{c}\text { 牛乳 } \\
\text { 摂取開始後 }\end{array}$ & 飲用牛乳 & $\begin{array}{c}\text { アレルギー症状 } \\
\text { その他 }\end{array}$ \\
\hline 1 か月 & $0.02 \sim 0.05 \mathrm{ml}$ & \\
\hline 2 か月 & $0.05 \mathrm{ml}$ & 時々, 咳と鼻水：抗ヒスタミン薬内服 \\
\hline 3 か月 & $0.07 \mathrm{ml}$ & \\
\hline 4 か月 & $0.09 \mathrm{ml}$ & 数回の咳嗽 \\
\hline 5 か月 & $0.1 \mathrm{ml}$ & \\
\hline 6 か月 & $0.1 \mathrm{ml}$ & \\
\hline 7 か月 & $0.12 \mathrm{ml}$ & \multirow{6}{*}{ 時々口腔粘膜症状が出現し食事に混ぜて摂取 } \\
\hline 8 か月 & \multirow{5}{*}{$0.15 \mathrm{ml}$} & \\
\hline 9 か月 & & \\
\hline 10 か月 & & \\
\hline 12 か月 & & \\
\hline 13 か月 & & \\
\hline
\end{tabular}



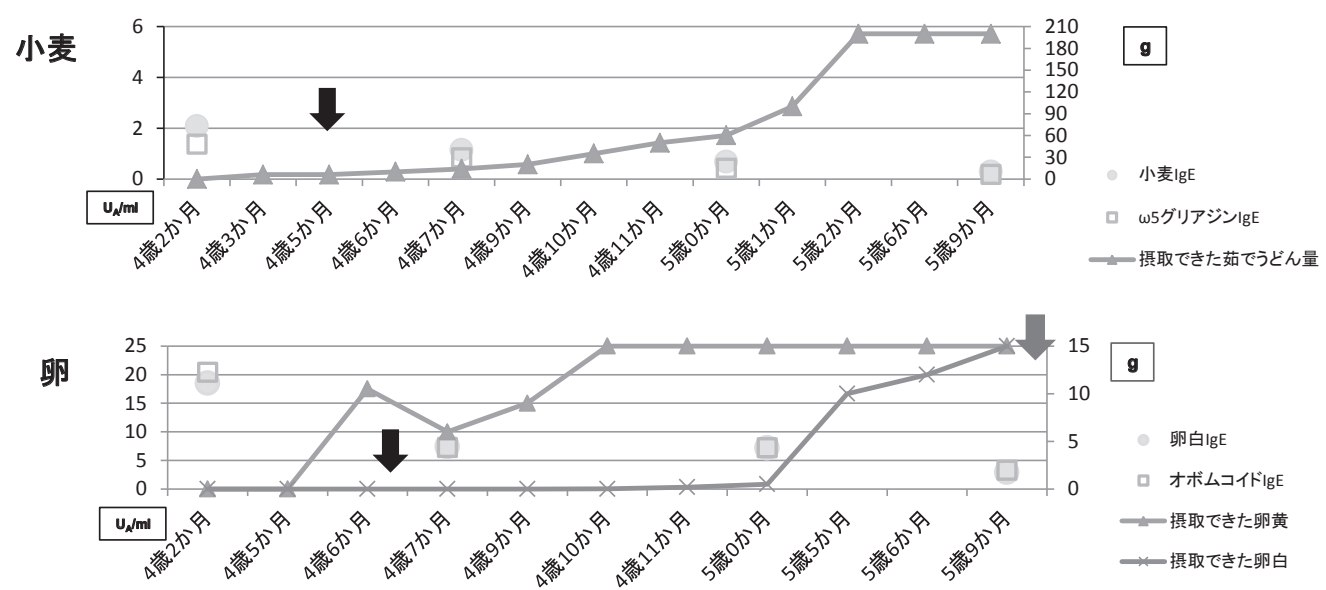

牛乳

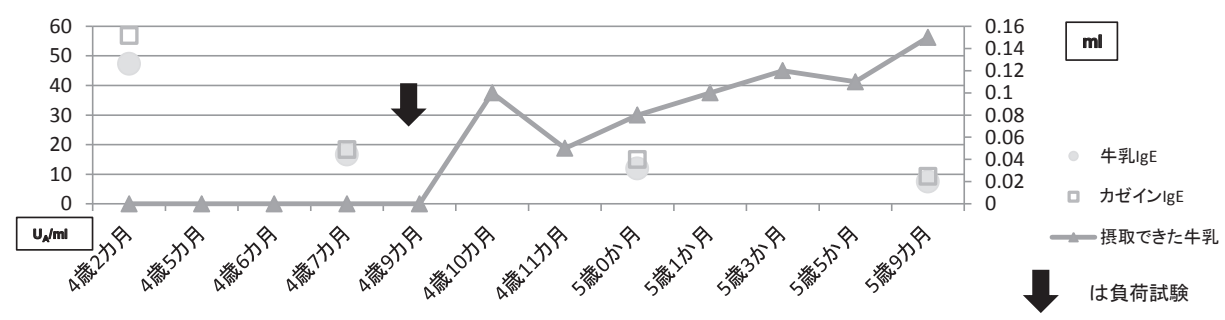

Fig. 1 Change of specific IgE and Development of tolerance to Foods.

Table 3 Change of serum total $\operatorname{IgE}$ and specific $\operatorname{IgE}$.

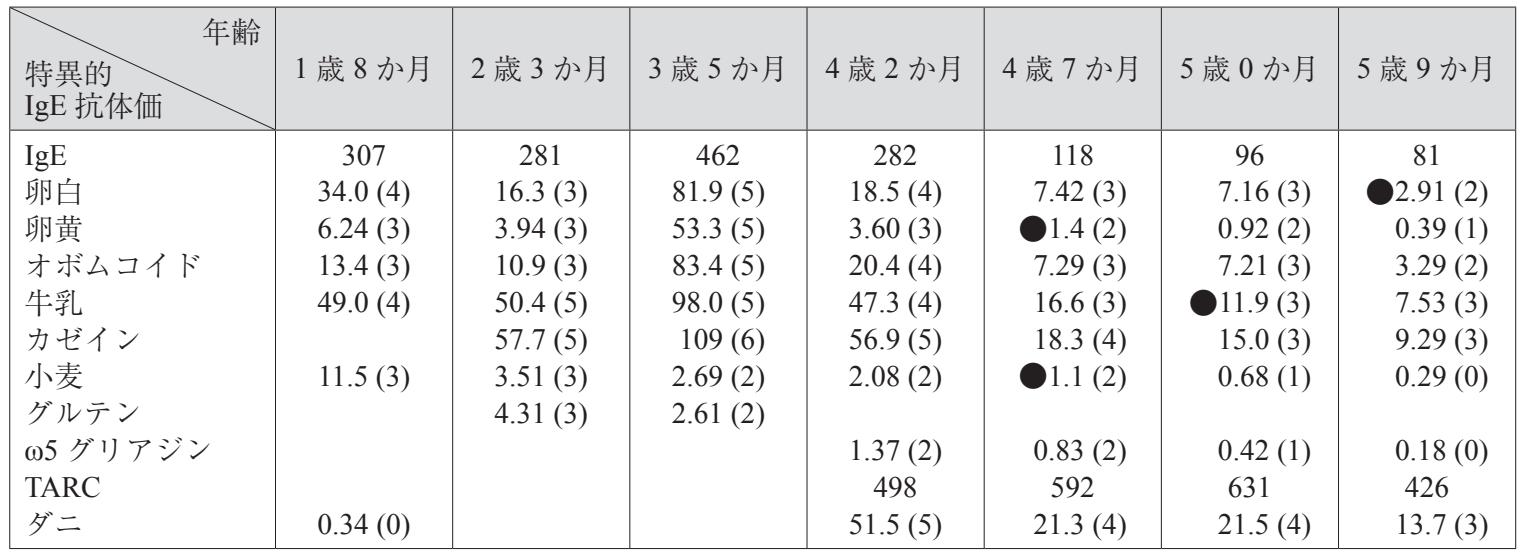

(O) は特異的 $\operatorname{IgE}$ のクラス は負荷試験後

指導開始後の抗原特異的 $\operatorname{IgE}$ 抗体価の低下は耐性獲得の 機序と関係していると考えている。しかし，本症例は牛 乳の脱感作に難啮しており, 今後は他の治療法について も検討が必要と感じている。

\section{結語}

卵，牛乳，小麦を完全除去中の食物アレルギー児に対 して，OFCの結果に基づいて外来でアレルゲン食品を 徐々に増量していく緩徐法による食事指導を行ったとこ ろ, OIT でなくとも「安全域を見込んだ摂取量の範囲」 で経口免疫寛容の獲得が可能となった。 その結果，小麦 と卵の制限解除が出来て, 料理献立の種類が幅広くなっ
た症例を経験した

\section{倫理的配慮}

本症例では OFC は文書にて, 食事指導につきまして は口頭にて説明と同意を得た。また報告するにあたり， 患者のプライバシーに十分配慮し, 口頭でインフォーム ドコンセントを行ったうえで保護者からの同意を得た。

\section{利益相反に関する開示}

著者は本論文の研究内容について開示事項はない. 


\section{文献}

1）伊藤浩明. 即時型食物アレルギー診療の今. 小览喘息情 報誌 2016; 15: 6-7.

2) S. Allan Bock. Prospective Appraisal of Complaints of Adverse Reactions to Foods in Children During the First 3 Years of Life. PEDIATRICS 1987; 79: 683-688.

3）池松か子り，田知本寞，杉崎千鶴子，他．乳児期発症食 物アレルギーに関する検討 (第 2 報)一卵・牛乳・小麦・ 大豆アレルギーの 3 歳までの経年的変化一. アレルギー 2006; 55: 533-541.

4) Sampson HA, Scanlon SM. Natural history of food hypersensitivity in children with atopic dermatitis. $J$ pediatr 1989; 115: 23-27.

5）今井孝成，小俣貴嗣，緒方美佳，他．遷延する食物アレ ルギーの検討。アレルギー 2007; 56: 1285-1292.

6）栗原和幸．食物アレルギーの経口免疫療法（経口耐性誘 導). J Environ Dermatol Cutan Allergol 2011; 5: 365-372.

7）伊藤浩明監修。おいしく治す食物アレルギー攻略法. 支 援ネットワーク 2014; 11 .
8）今井孝成，海老澤元宏．全国経口食物負荷試験実施状況 一平成 23 年即時型食物アレルギー全国モニタリング調 査から一。 アレルギー 2013; 62: 681-688.

9) Bruks AW, Tang M, Sicherer S, et al. ICON: food allergy. $J$ Allergy Clin Immunol 2012; 129: 906-920.

10）伊藤浩明。必要最小限の除去一不適切な診療によるピッ トフォール．臨床栄養 2015; 126(2): 141-145.

11）日本小児アレルギー学会食物アレルギー委員会. 食物ア レルギー診療ガイドライン 2016. 協和企画.

12）栗原和幸．食物アレルギーに対する経口免疫療法．チャ イルドヘルス 2015; 18(9): 15-18.

13）加工食品のアレルゲン含有早見表検討委員会. 加工食品 のアレルゲン含有量早見表. 平成 27 年 3 月 15 日発行.

14）漢人直之，伊藤浩明。除去食解除のための食事指導。ア レルギー 2013; 62: 266.

15）伊藤節子．食物アレルギー患者指導の実際．アレルギー 2009; 58: 1490-1496.

16）小林貴江, 漢人直之, 羽根田泰宏, 他. 食物経口負荷試 験の結果に基づくアレルゲン食品摂取指導（第 1 報）. 日本小児アレルギー学会誌 2013; 27: 179-187. 